\title{
海洋構造物の防食技術
}

\author{
蒔田實* \\ *建設省土木研究所
}

\section{Corrosion Protection Technology of Marine Structures}

\author{
Minoru Makita*
}

*Public Works Research Institute, Ministry of Construction

\begin{abstract}
Key words; marine environment, marine structure corrosion of steel, low-alloy corrosion resistant steel, stainless steel, titanium alloy, polyethylene lining resin mortar lining, heavy duty coating, fibre-concrete lining, cathodic protection.
\end{abstract}

\section{1. まえがき}

近年, 我が国において海上長大橋, 河口堰などの大型 構造物が建設されて扣り,さらに今後も, 国土の狭小な 我が国に扣いては沿岸海域のスペース利用がきわめて重 要であるとの観点から, 海上空港, 海上都市, 海上廃棄 物処理施設, 海底沈埋トンネル, 浮防波堤など, 海底に 固定あるいは海中に浮遊した各種の構造物の建設が計画 され，あるいは検討されている。海洋は陸上とは比較に ならないほどの激しい腐食性を有する環境であるため, 海洋構造物にはその耐久性を確保するための十分な防錆 防食対策が必要とされる。しかし, 海洋石油掘削装置,

海洋土木作業台, シーバース等の従来の海洋構造物の防 食方法の耐用年数は短く, 比較的頻繁な補修を要し, 保 守管理に多大の経費を要している。今後開発の期待され ている海洋構造物は，いずれも大規模で 50 年あるいは 100 年といった非常に長い耐用年数を期待するものであ るだけにより耐久性の優れた新しい防食技術の開発を 図らない限り，このような大規模な海洋構造物の実用化 は極めて困難なものとなる。

以上のような情況を背景に, 近年, 海洋構造物の防食 技術の開発研究が各方面で積極的に進められている。本 文では, 海洋構造物の防食技術の現状と問題点について 解説する。

* $\bar{\top} 305$ 茨城県筑波郡豊里町大字旭 1 (1-Oaza-Asahi, Toyosato-Machi, Tsukuba-gun, Ibaraki-ken, 305 Japan)

\section{2. 海洋構造物の防食技術}

\section{1 海洋環境における鋼材の腐食}

\subsection{1 環境条件と腐食傾向}

海洋に括ける鋼の腐食傾向は，一般に図 1 のようにな ることが知られている。すなわち, 飛洙部が最も腐食が 激しく，腐食速度が最大となる。しかし，干満部になる にしたがって腐食速度は低下し, 海中部に入ると海面直 下で再び大きくなり極大值をとる。さらに水深が深くな るにつれて腐食速度は低下する。腐食速度が干満部で小 さく，海面直下で極大值をとるのは，海水面をはさんで 酸素の濃淡による腐食電池が形成されるためである。す なわら，図 1 のような腐食傾向を示すのはあくまで鋼材 が海上大気中から海中まで連続して異なる環境に接する 場合である。したがって鋼材がそれぞれの環境に別々に

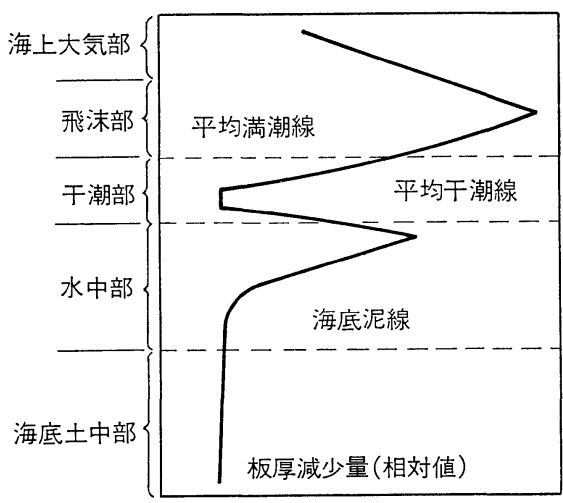

図 1 環境条件と鋼の腐食傾向（シートパイルの腐 食, Kure Beach 5 年の結果 ${ }^{1)}$ ) 
接する場合には, 図 2 の実線のような腐食傾向を示し, 当然の事ながら酸素濃淡電池が形成されないため, 水面

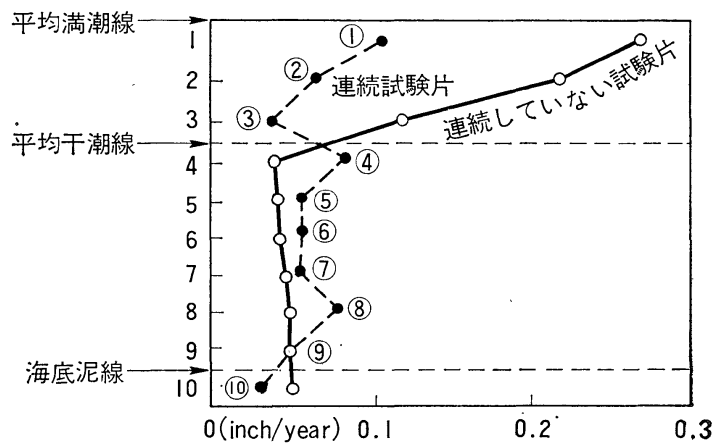

図 2 連続した場合と連続しない場合の試験片の腐 食速度 ( 6 ケ月暴露 $)^{1)}$

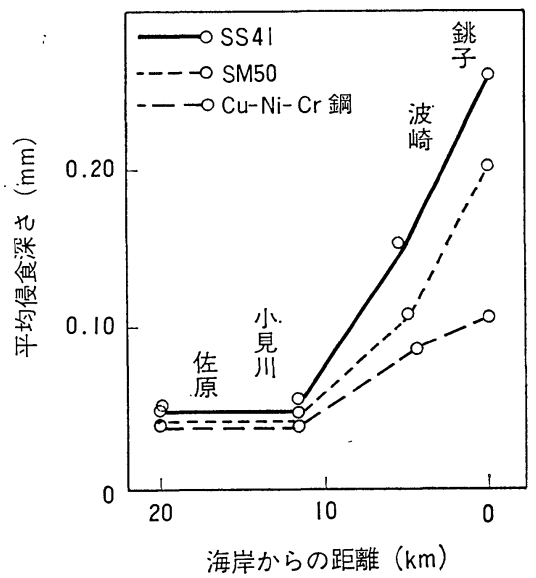

(a)
直下の海中部より干満部の腐食速度の方が大きくなる。

\subsection{2 各環境条件下での腐食速度}

(1) 海上大気中

大気中に抢ける鋼材の腐食は, 雨量, 湿度, 気温, 日 照量, 大気污染物質 (亜硫酸ガス等) や海塩粒子の影響 を受けるが，腐食量 $\left(Y ; \mathrm{mg} / \mathrm{dm}^{2} \cdot \mathrm{day}\right)$ 亿最も影響を与 えるのは海塩粒子 $\left(X_{1} ; \mathrm{Cl} \mathrm{mg} / \mathrm{dm}^{2} \cdot\right.$ day $)$ 及び亜硫酸ガ 不量 $\left(X_{2} ; \mathrm{SO}_{3} \mathrm{mg} / \mathrm{dm}^{2} \cdot\right.$ day $)$ で, およ乞次式の関係に あるといわれている。

$$
Y=4.4+39.7 X_{1}+3.74 X_{2}{ }^{2)}
$$

すなわち，海上大気中にある鋼材の腐食は，海塩粒子の 影響を受けて, 陸上大気中に比較して著しく促進され る。海塩粒子の影響を示す調査結果の一例を図 3 に示 す。

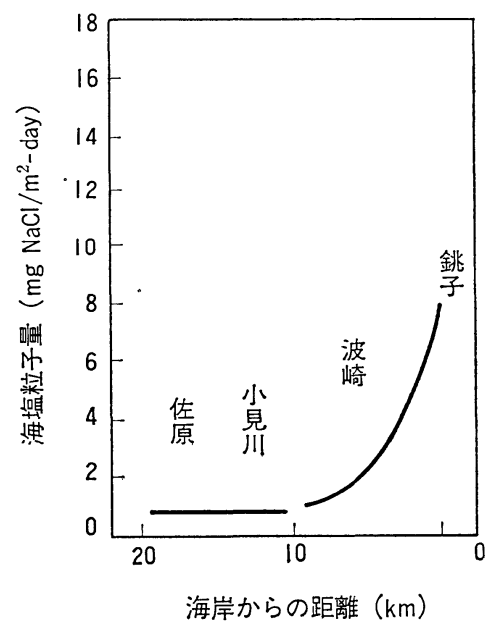

(b)

図 3 海岸からの距離と腐食量及び海塩粒子量 ${ }^{3)}$

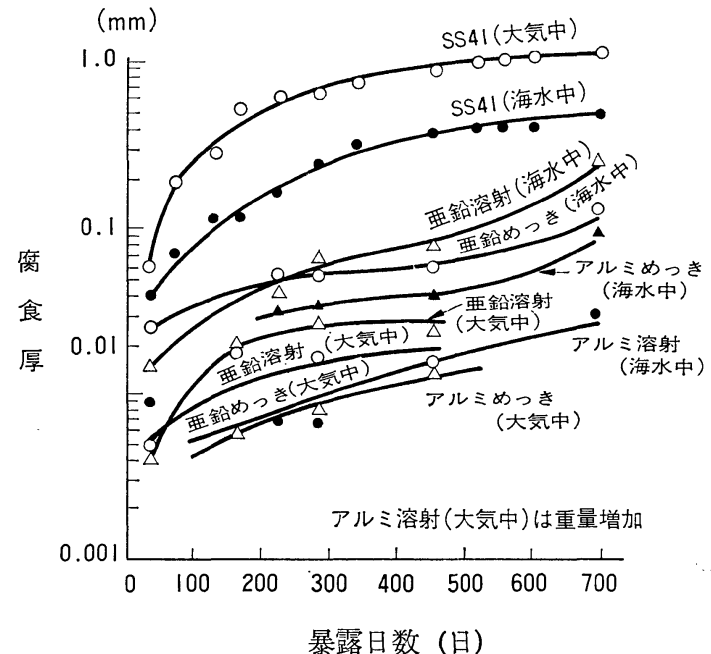

暴露日数（日）

(a) 川崎沖

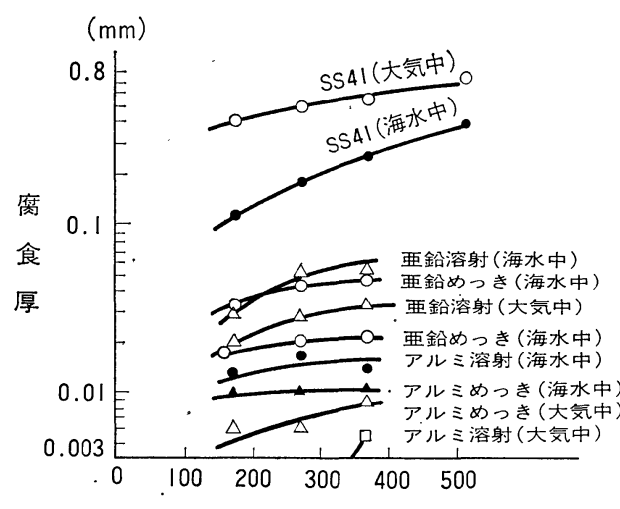

暴露日数（日）

(b) 木更津沖

図 4 飛洙帯（大気中）にお打鋼と金属被覆の腐食速度 ${ }^{4}$ 
(2) 飛 洙 部

平均満潮線より少し上の部分の海水のしぶきのかかる 飛沫部は，最も腐食の激しい箇所で，鋼材の腐食は全面 腐食と局部腐食の混った形態をとり，腐食生成物は硬く て厚いフレーク状を呈する。腐食速度は $1 \mathrm{~mm} / Y$ に達 することもある。飛洙部の鋼材等の腐食量の調査結果の

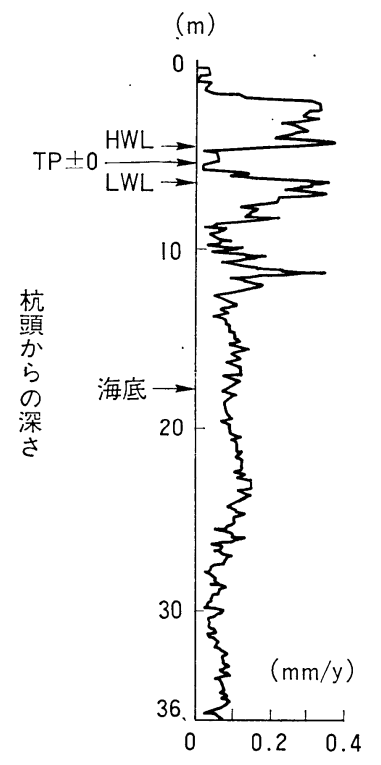

腐食速度

（a）電気防食なし (m)

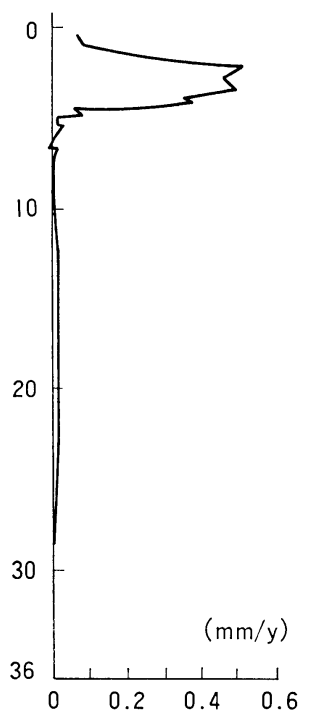

腐食速度

（b）電気防食あり
図 5 鋼管杭の水深方向の腐食速度 ${ }^{5)}$ （東京湾・川崎沖）

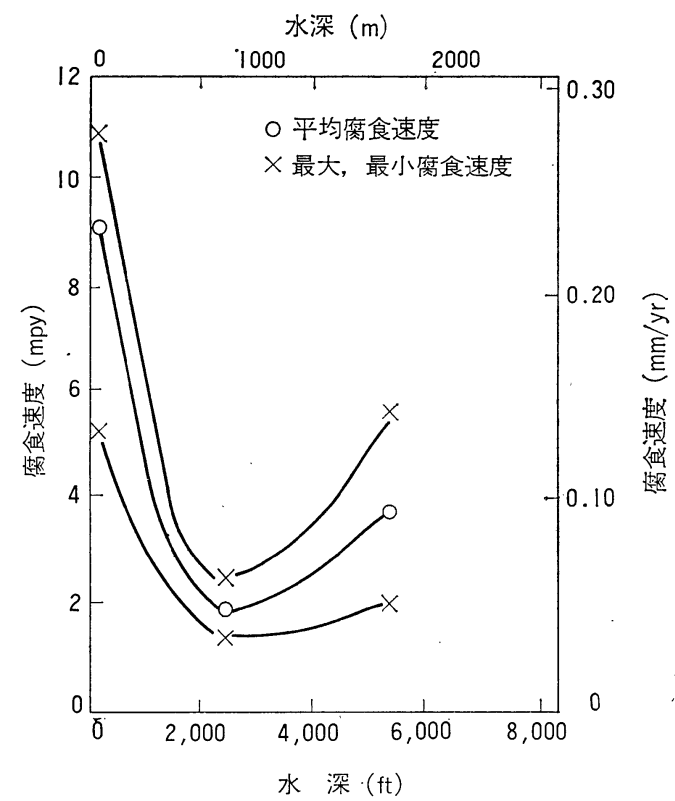

一例を図 4 に示す。

(3) 干 満 部

潮の干満により周期的に浸漬と露出がくり返され，飛 沫部とよく似た環境であるが，図 2 亿示す通り，鋼材の 設置状況によって腐食速度が異なる。

(4) 海 中 部

海水面直下で局所的に腐食速度が大きくなるが，水深 が深くなるにつれて腐食速度は減少し，浅海ではほぼ一 定の值となる。しかし，海域によっては水深方向に水質 の異なる海水が層状に存在する場合なぞ，特定の水深部 分で局所的に腐食速度が大きくなる場合もある。このよ らな実例の一つを図 5 に示す。

深海での腐食は（図６に示すように), 溶存酸素の分 布と関連し，大深度では腐食速度が減少する。

海中での鋼材の腐食速度は，上述の溶存酸素のほか， 水温, 流速等の影響を受ける。 $5^{\circ} \mathrm{C}$ 以下にもなるオホー ツク海に比べて $30^{\circ} \mathrm{C}$ 近くになる熱帯海域では腐食速度 は2 倍にもなる。また，潮流のある場合には流速が大き くなるにしたがって，腐食速度は大きくなる。

\section{2 各種海洋構造物の防食技術の現状}

我が国に括ける各種海洋構造物に実際に用いられてい る防食方法の現況を表 1 亿示す。

鋼材は主として普通鋼が用いられているが，一部に耐 候性鋼や耐海水鋼も使用されている。各構造物とも腐食 環境及び部位によって異なった防食方法が採用されてい る。一般に海上大気部及び飛沫部では重防食塗装を施し たものが多く，海中及び海底土中部では電気防食が行わ れている。

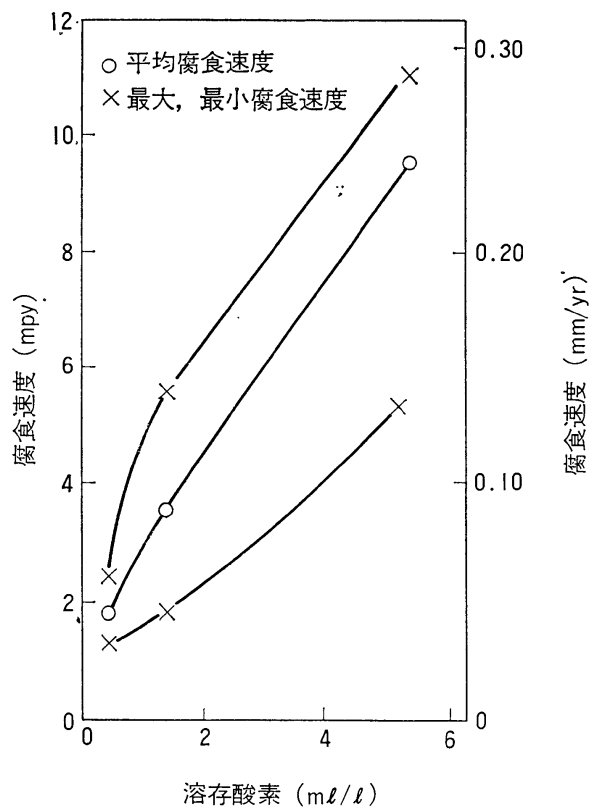

図 6 大水深海域に括ける水深と腐食速度及び溶存酸素 ${ }^{2)}$ 
表 1 我が国の海洋構造物の防食方法の概要1)

\begin{tabular}{|c|c|c|c|c|c|c|}
\hline \multirow{2}{*}{ 分 } & \multirow{2}{*}{$\begin{array}{l}\text { 調 } \\
\text { 查 } \\
\text { 件 } \\
\text { 数 }\end{array}$} & \multirow{2}{*}{ 鋼 材 } & \multicolumn{2}{|c|}{ 防 } & 法 & \multirow{2}{*}{ 備 } \\
\hline & & & 海上大気部 & 飛 沫 带 & 海中 · 海底土中 & \\
\hline $\begin{array}{l}\text { 海洋石油掘削 } \\
\text { 装置 (リグ) }\end{array}$ & 12 & $\begin{array}{l}\text { 普通鋼または } \\
\text { 普通鋼十高張 } \\
\text { 力鋼の仿用 }\end{array}$ & $\begin{array}{l}\text { 塗 装 a) } \\
\left(\begin{array}{l}\text { ジンクリッチプ } \\
\text { ライマー十エポ } \\
\text { キシまたはター } \\
\text { ルエポキシ系 }\end{array}\right)\end{array}$ & $\begin{array}{l}\text { 重叙装 } \\
\text { (同左) } \\
\text { 一部電気防食の併 } \\
\text { 用あり }\end{array}$ & $\begin{array}{l}\text { 電気防食または電防 } \\
\text { 十塗装 } \\
\text { 電防：Al 陽極 } \\
\text { 叙装：同左 }\end{array}$ & 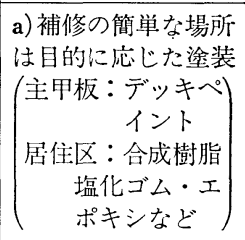 \\
\hline $\begin{array}{l}\text { 海洋土木作業 } \\
\text { 台 } \\
\left(\begin{array}{l}\text { プラット } \\
\text { フォーム } \\
\text { b) }\end{array}\right)\end{array}$ & 9 & 同上 & $\begin{array}{l}\text { 塗 装 } \\
\left(\begin{array}{l}\text { ウォシュプラ } \\
\text { イマー十合成樹 } \\
\text { 脂系 }\end{array}\right)\end{array}$ & $\begin{array}{l}\text { 重塗装 } \\
\left(\begin{array}{l}\text { ウォッシュプラ } \\
\text { イマー十エポキ } \\
\text { シまたはタール } \\
\text { エポキシ系 }\end{array}\right)\end{array}$ & \begin{tabular}{|l|} 
雓 装 \\
(同左) \\
電気防食との併用 \\
は少ない
\end{tabular} & $\begin{array}{l}\text { b)自己昇降式作業台 } \\
\text { (SE E)は補修が可 } \\
\text { 能なためリグや固定 } \\
\text { 式作業台に比べて防 } \\
\text { 食性に少る叙装系が } \\
\text { 採用されている }\end{array}$ \\
\hline シーバース & 45 & $\begin{array}{l}\text { (1)棧橋・ドル } \\
\text { フィン方式 } \\
\text { は同上 } \\
\text { (2)係留方式は } \\
\text { 普通鋼のみ }\end{array}$ & - & $\begin{array}{l}\text { 重塗装 } \\
\left(\begin{array}{l}\text { 無機ジンクリッチ } \\
\text { プライマー, ター } \\
\text { ルエポキシまたは } \\
\text { 無機ジンクリッチ } \\
\text { プライマー+ター } \\
\text { ルエポキシ }\end{array}\right)\end{array}$ & $\begin{array}{l}\text { 電気防食または電阬 } \\
\text { ＼cjkstart塗装 } \mathrm{c}) \\
\left(\begin{array}{c}\text { 電防： } \mathrm{Al} \text { 陽極 } \mathrm{d}) \\
\text { 塗装：タールエポ } \\
\text { キシ }\end{array}\right) \\
\text {. }\end{array}$ & $\begin{array}{l}\text { c) 塗装以外に一部ア } \\
\text { スファルトなどのラ } \\
\text { イニングあり } \\
\text { d)古いものは外部電 } \\
\text { 源方式のほうが多い }\end{array}$ \\
\hline $\begin{array}{l}\text { 海中展望塔e) } \\
\text { 海中レストラ } \\
\text { ン } \\
\text { アクアポリス } \\
\text { •• }\end{array}$ & 6 & $\begin{array}{l}\text { 普通鋼または } \\
\text { 普通鋼十高㖘 } \\
\text { 力鋼の併用 }\end{array}$ & $\begin{array}{l}\text { 塗 装 } \\
\text { エポキシまたは合 } \\
\text { 成樹脂系など } \\
\text { ·· }\end{array}$ & $\begin{array}{l}\text { 重塗装 } \\
\text { エポキシまたは夕 } \\
\text { ールエポキシ系 }\end{array}$ & $\begin{array}{l}\text { 電防十叙装 } \\
\left(\begin{array}{c}\text { 電防：Al 陽極 } \\
\text { 塗装：エポキシ系 } \\
\text { または塗装 }\end{array}\right) \\
\text { (タールエポキシ). }\end{array}$ & $\begin{array}{l}\text { e) 海中展望塔の調査 } \\
4 \text { 件中 } 2 \text { 件は各環境 } \\
\text { ともF R Pライニン } \\
\text { グ }\end{array}$ \\
\hline $\begin{array}{lll}\text { 観 } & \text { 測 } & \text { 塔 } \\
\text { 灯 } & & \text { 標 } \\
\text { ブ } & & \text { イ. } \\
\text { 実 } & \text { 験 } & \text { 台 }\end{array}$ & 19 & $\begin{array}{l}\text { 普通鋼 } \\
\left(\begin{array}{l}\text { 一部耐候 } \\
\text { 性鋼, 耐 } \\
\text { 海水性鋼 } \\
\text { が併用 }\end{array}\right)\end{array}$ & $\begin{array}{l}\text { 塗 装 } \\
\text { エポキシ，タール } \\
\text { エポキシまたは合 } \\
\text { 成樹脂 }\end{array}$ & $\begin{array}{c}\text { 重塗装 f) } \\
\text { (同左) }\end{array}$ & $\begin{array}{l}\text { 塗装または電防十塗 } \\
\text { 装 } \\
\left(\begin{array}{c}\text { 電防： } \mathrm{Al} \text { または } \\
\mathrm{Zn} \text { 陽極 } \\
\text { 叙装：合成樹脂ま } \\
\text { たはタール } \\
\text { エポキシ系 }\end{array}\right) .\end{array}$ & $\begin{array}{l}\text { f)灯標の飛沫带で一 } \\
\text { 部, 樹脂, コンクリ } \\
\text { 一ト, ステンレスな } \\
\text { どのライニングあり }\end{array}$ \\
\hline $\begin{array}{l}\text { 海 底 } \\
\text { パイプライン }\end{array}$ & 25 & 普通鋼 & - & - & $\begin{array}{l}\text { パイプ外面: 電防+ } \\
\text { 叙覆装 } \\
\text { (電防：外部電源方 } \\
\text { 式が主体 } \\
\text { 塗覆装：コンクリ } \\
\text {-ト+アス } \\
\text { ファルト系) } \\
\text { パイプ内面：防食な } \\
\text { しが多い }\end{array}$ & - \\
\hline $\begin{array}{l}\text { 沈埋トンネル } \\
\text { g) }\end{array}$ & 4 & 普通鋼 & - & - & $\begin{array}{l}\text { 電阬十雓装 h) } \\
\left(\begin{array}{c}\text { 電防：外部電源 } \\
\text { 塗装：タールエポ } \\
\text { キシ }\end{array}\right)\end{array}$ & $\begin{array}{l}\text { g)すべてコンクリー } \\
\text { トの外面を鋼板で包 } \\
\text { んだ構造 } \\
\text { h) 塗装なし電防のみ } \\
\text { もあり } \\
\end{array}$ \\
\hline
\end{tabular}

\section{3 防食技術開発の現況と問題点}

\subsection{1 海上大気部の防食技術}

海洋構造物の大気中の部位は, 他の部位に比べては補 修が容易であること, 美観上あるいは安全上の点から着 色が必要とされることにより, 今後も防食技術として塗 装が行われていくものと考兄られる。他の部位に比べて 補修が容易とはいっても海上作業であり, 気象条件の影 響, 付着塩分の除去等作業は困難な点が多い。また, 比
較的頻繁な補修柱莫大な維持経費を要することにもな る。このようなことから, 近年長期防錆型塗装系の開発 研究が積極的に進められ, 関門橋, 本州四国連絡橋等の 海上長大橋には耐久性に優れた新しい長期防錆型の塗装 系が採用されてきている。

近年の技術開発の結果から, 海洋構造物に適した長期 防錆型の塗装系として, 表 2 の塗装系が取りあげられて いる。これらの塗装系は, 従来の塗装系に比べて耐久性 
は格段に優れていると考えられるが，長年月の間には劣 化するものであり，やがては塗替えを必要とする。

表 2 亿打ける塗装系 A, B, C, D は, 着色が自由で あり，実績からいって最も信頼性の高いものであるが， 何といっても塗り重漦回数が多く, 補修時の海上作業と
いら条件下で果たして的確な施工が行い得るものかぞう か, 塗替兄後十分な耐久性が得られるか否か, 問題点が 多いと考えられる。叙装系 $\mathrm{E}$ は，実績も多く信頼性は高 いが，着色が自由にならない点で適用䇢所が限定され る。また, 塗装系 $\mathrm{F} は$ 着色も自由で耐久性も優れてお

表 2 海上大気部に適用する塗装系 (上塗りまで工場で塗装) ${ }^{8)}$

\begin{tabular}{|c|c|c|c|c|c|c|c|c|c|}
\hline $\begin{array}{l}\text { 鋈 } \\
\text { 装 } \\
\text { 系 }\end{array}$ & $\begin{array}{l}\text { 素 調 } \\
\text { 地 整 }\end{array}$ & 第 1 層 & 第 2 層 & 第 3 層 & 第 4 層 & 第 5 層 & 第 6 層 & 第 7 層 & \multirow{7}{*}{\begin{tabular}{|l} 
記号 $($ 塗料名 $)$ \\
$\mathrm{H} \cdot \mathrm{Z}:$ 厚膜無機ジンク \\
$\mathrm{Z} \quad:$ 無機ジンク \\
$\mathrm{M} \quad:$ ミストコート \\
$\mathrm{HE}:$ : 厚膜型エポキシ \\
$\mathrm{PU}:$ ポリウレタン \\
$\mathrm{H} \cdot \mathrm{V}:$ 厚膜ビニル \\
$\mathrm{Ph} \cdot \mathrm{Z}:$ フェノールジンクフロメート \\
$\mathrm{Ph} \cdot \mathrm{M} 10:$ フェノールM 10 \\
$\mathrm{Ch}:$ 塩化ゴム \\
$\mathrm{H} \cdot \mathrm{ME}$
\end{tabular}} \\
\hline A & \multirow{6}{*}{$\begin{array}{l}\text { ブ } \\
\text { ラ } \\
\text { ス } \\
\text { ト }\end{array}$} & $\mathrm{H} \cdot \mathrm{Z}$ & $M$ & $\mathrm{H} \cdot \mathrm{E}$ & $\mathrm{H} \cdot \mathrm{E}$ & $\mathrm{PU}$ & $\mathrm{PU}$ & - & \\
\hline B & & " & \begin{tabular}{|l|} 
JISK- \\
5633 (1種)
\end{tabular} & $\mathrm{H} \cdot \mathrm{V}$ & $\mathrm{H} \cdot \mathrm{V}$ & $\mathrm{H} \cdot \mathrm{V}$ & $\mathrm{H} \cdot \mathrm{V}$ & - & \\
\hline $\mathrm{C}$ & & " & " & $\mathrm{Ph} \cdot \mathrm{Z}$ & $\mathrm{Ph} \cdot \mathrm{M} 10$ & $\mathrm{Ph} \cdot \mathrm{M} 10$ & $\mathrm{Ch}$ & $\mathrm{Ch}$ & \\
\hline $\mathrm{D}$ & & $\mathrm{Z}$ & $\mathrm{H} \cdot \mathrm{ME}$ & $\mathrm{H} \cdot \mathrm{ME}$ & $\mathrm{H} \cdot \mathrm{ME}$ & $\mathrm{H} \cdot \mathrm{ME}$ & - & - & \\
\hline $\mathrm{E}$ & & " & $\mathrm{T} \cdot \mathrm{E}$ & $\mathrm{T} \cdot \mathrm{E}$ & $\mathrm{T} \cdot \mathrm{E}$ & - & - & - & \\
\hline $\mathrm{F}$ & & $\begin{array}{c}\text { プライ } \\
\text { マー }\end{array}$ & $\mathrm{GF} \cdot \mathrm{PE}$ & $\mathrm{GF} \cdot \mathrm{PE}$ & - & - & - & -. & \\
\hline
\end{tabular}

表 3 飛沫帯・干満帯部の防食被覆9

\begin{tabular}{|c|c|c|c|c|c|c|c|c|c|c|}
\hline \multirow{2}{*}{ 分 } & \multirow{2}{*}{ 被 覆 の 種 類 } & \multicolumn{2}{|c|}{ 杭 } & 試験片 & \multirow{2}{*}{ 分 類 } & \multirow{2}{*}{ 被 覆 の 種 類 } & \multicolumn{2}{|c|}{ 杭 } & \multicolumn{2}{|c|}{ 試験片 } \\
\hline & & C & $\mathrm{A}$ & \begin{tabular}{l|l}
$\mathrm{C}$ & $\mathrm{A}$
\end{tabular} & & & C & $\mathrm{A}$ & C & A \\
\hline \multirow{5}{*}{ 金属被覆 } & $\begin{array}{c}\text { 耐海水鋼 }\left(\mathrm{Cu}^{-} \mathrm{Cr}-\mathrm{Al} \text { 系) }\right. \\
\text { 卷き }(6 \mathrm{~mm}) \\
\end{array}$ & 0 & C & 00 & 有、機 質 & $\begin{array}{r}\text { ガラスフレークスりポリエステル } \\
(1 \mathrm{~mm})\end{array}$ & & & 0 & \\
\hline & $\begin{array}{c}\text { ステンレス鋼 }(25 \mathrm{Cr}-13 \mathrm{Ni} \text { 系 }) \\
\text { 卷き }(3 \mathrm{~mm})\end{array}$ & 0 & & 0 & $\left(\begin{array}{l}\text { ポリエス } \\
\text { テル }\end{array}\right)$ & $\begin{array}{r}\text { ガラスフレークスりポリエステル } \\
(2 \mathrm{~mm})\end{array}$ & & & 0 & \\
\hline & モネル巻き $(2 \mathrm{~mm})$ & & & 0 & \multirow{5}{*}{$\begin{array}{l}\text { 同 上 } \\
\left(\begin{array}{l}\text { ポリエチ } \\
\text { レン }\end{array}\right)\end{array}$} & ポリエチレン(押出し成形， $4 \mathrm{~mm}$ ) & 0 & 18 & 0 & O \\
\hline & チタンクラッド $(0.5 \mathrm{~mm})$ & & & 0 & & ポリエチレン(押出し成形， $4 \mathrm{~mm}$ ) & & & & $\checkmark$ \\
\hline & $\begin{array}{l}\text { アルミ溶射 }(100 \mu \mathrm{m})+\text { タールエ } \\
\text { シ }(300 \mu \mathrm{m} \times 2)\end{array}$ & 0 & & 0 & & 紛体ポリエチレン $(8 \mathrm{~mm})$ & & & 0 & \\
\hline \multirow{4}{*}{$\begin{array}{l}\text { 金属溶射 } \\
\text { +塗装 }\end{array}$} & $\begin{array}{l}\text { アルミ溶射 }(100 \mu \mathrm{m}) \times \text { ビニロンクロス } \\
\text { 補強タールエポシ }(300 \mu \mathrm{m} \times 3)\end{array}$ & 0 & & O & & $\begin{array}{c}\text { ポリエチレンシュリンクチューブ } \\
(3 \mathrm{~mm})\end{array}$ & & & O & \\
\hline & $\begin{array}{l}\text { アルミ溶射 }(100 \mu \mathrm{m})+\text { ガラスクロス補 } \\
\text { 強夕ールエポキシ }(300 \mu \mathrm{m} \times 3)\end{array}$ & & 0 & O & & 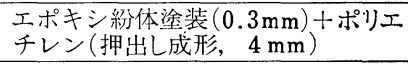 & & & O & 0 \\
\hline & アルミ溶射 (封孔処理, $200 \mu \mathrm{m}$ ) & 0 & & 0 & \multirow{3}{*}{$\left(\begin{array}{l}\text { ポリウレ } \\
\text { タン }\end{array}\right)$} & ポリウレタンゴム $(4 \mathrm{~mm})$ & & 0 & & O \\
\hline & $\begin{array}{r}\text { 亜鉛溶射 }(100 \mu \mathrm{m})+タ \text { タルエポキシ } \\
(300 \mu \mathrm{m} \times 2)\end{array}$ & 0 & & O & & 発泡ポリウレタン $(10 \mathrm{~mm})$ & & & 0 & \\
\hline \multirow{3}{*}{ 塗装 } & $\begin{array}{l}\mathrm{HB} \text { 無機ジンク }(75 \mu \mathrm{m})+\text { タールエ } \\
\text { ポキシシ }(300 \mu \mathrm{m} \times 3)\end{array}$ & 0 & C & 0 & & ウレタンマスチック $(3 \mathrm{~mm})$ & & 0 & & 10 \\
\hline & $\begin{array}{l}\mathrm{HB} \text { 無機ジンク }(75 \mu \mathrm{m})+\text { ガラスクロ } \\
\text { ス補強エポキシ }(300 \mu \mathrm{m} \times 3)\end{array}$ & O & O & 00 & \multirow{4}{*}{ 同 上の他) } & プチルゴム $(4 \mathrm{~mm})$ & & & 0 & \\
\hline & $\begin{aligned} \mathrm{HB} \text { 無機ジンクリッチペイント } & \begin{array}{r}(100 \mu \mathrm{m}) \\
\end{array}\end{aligned}$ & & & 0 & & クロロプレンゴムシート $(5 \mathrm{~mm})$ & & & O & \\
\hline \multirow{6}{*}{$\begin{array}{l}\text { 有 機 質 } \\
\text { ライニング } \\
\text { (エポキシ) }\end{array}$} & $\begin{array}{l}\text { レジジモルタル } \\
(\text { エポキシ } 20 \mathrm{wt} \%, 4 \mathrm{~mm})\end{array}$ & O & IC & 0 & & アスファルトマスチック $(10 \mathrm{~mm})$ & & & 0 & \\
\hline & $\begin{array}{l}\text { レジンモルタル } \\
(\text { エポキシ } 33.3 \mathrm{wt} \%, 5 \mathrm{~mm})\end{array}$ & & & $\mathrm{O}$ & & $\begin{array}{l}\text { ペロトラタム含浸テープ }(2 \mathrm{~mm})+ \\
\mathrm{FRP}(3 \mathrm{~mm})\end{array}$ & & & 0 & \\
\hline & $\begin{array}{r}\text { ガラス・レークスりエポキシ } \\
(2 \mathrm{~mm})\end{array}$ & & & 0 & \multirow{4}{*}{$\begin{array}{l}\text { 無 機 質 } \\
\text { ライニング }\end{array}$} & スチールファイバーコンクリート & O & & & \\
\hline & 水中硬化型エポキシ $(5 \mathrm{~mm})$ & & & 0 & & スチールファイバーコンクリート & 0 & & & \\
\hline & $\begin{array}{r}\text { タールエポキシマスチック } \\
(14 \mathrm{~mm})\end{array}$ & & & 0 & & $\begin{array}{r}\text { セメントモルタル }(47 \mathrm{~mm})+\mathrm{FRP} \\
(3 \mathrm{~mm})\end{array}$ & & & & b \\
\hline & $\begin{array}{r}\text { 不織布含漫エポキシテープ } \\
(3 \mathrm{~mm})\end{array}$ & & & O & & $\begin{array}{r}\text { ガラス繊維入りセメントモルタル } \\
(20 \mathrm{~mm})\end{array}$ & & & & \\
\hline
\end{tabular}

注：(1) ○印は暴露場所 ( $\mathrm{C}$ : 東京湾千葉市沖, $\mathrm{A}$ : 茨城県阿字ヶ浦沖).

(2) 杭の大きき（Cでは $\phi 508 \mathrm{~mm}+l 45 \mathrm{~m}$ ・防食部分 $6 \mathrm{~m} ， \mathrm{~A} て ゙ は ~ \phi 609.6 \mathrm{~mm} \times l 16 \mathrm{~m}$ ・防食部分 $6 \mathrm{~m}$ ).

(3) 試験片の大きさ $\phi 100 \mathrm{~mm} \times l 2 \mathrm{~m}$. 
り, 塗り重初回数も少ない, と利点は多いが, 施工上に 問題点が残されて括り, 特に塗替え時の現地施工方法に は検討の余地が残されている。

以上述べたごとく耐久性に優れた長期防錆型塗装系が 開発されてきていて，大いに期待されるが，維持管理技 術を含めて一貫した技術としては，な扔今後の技術開発 の推進が期待されている。

\subsection{2 飛沫部，干満部の防食技術}

飛洙部，干満部では絶兄ず波浪，しぶきの影響を受け て腐食が最も激しいのみならず補修が極めて困難亡なる ため, 最も耐久性の優れた防食が必要とされる。従来の 海洋構造物では飛沫部, 干満部でも一般に重防食塗装が 行われているが，近年，飛洙部，干満部に適用する新し い防食材料の研究開発が進められている。その例を表 3 に示す。代表的な防食材料の約 10 年間の暴露試験結果 を表 4 亿示す。これら防食材料は構造物の形状等によっ ては必ずしも適用できないものもあり，これらの適用性 を表 5 に示す。

これらの防食材料の中には非常に耐久性の優れたもの
ああり，耐海水性のステンレス鋼などの金属被覆はメイ ンテナンスフリーと期待されるが，実構造物の適用衹当 たっては加工技術の確立とコスト的にどこまで合理化で きるかなどの課題が残されている。ポリェチレンライニ ング (押出し成型) は, 10 年間の実海域の暴露で生物付 着, 波浪等による損傷も非常に少なく，さらに長期の耐 久性が期待でさるが，鋼管板など円柱形の形状のものに しか適用できない。従来から一般に用いられてきた重防 食塗装よりはるかに耐久性の優れた防食材料が開発され ているが, それぞれ一長一短あり,海洋構造物の種類に応 ごて適材適所の利用をはかっていくことが重要である。

\subsection{3 海中及び海底土中部の防食技術}

海中及び海底土中部では電気防食が最も信頼性の高い 防食方法であり, 従来から一般に用いられている。電気 防食を行う場合には, 構造物の設置される環境条件に応 じて, 適切な防食電位及び防食電流密度を定める必要が ある。電気防食の方法には外部電源方式と儀牲陽極方式 の二通りの方式があるが, 従来の海洋構造物では一般に 犠牲陽極方式が行われている。

表 4 防食鋼管杭の調查結果のまとめ (千葉沖 $)^{9)}$

\begin{tabular}{|c|c|c|}
\hline 防 食 被 覆 の 種 類 & 被 覆 の 状 況 & 生物の付着状況 \\
\hline 処 & 全体的にかなり腐食が進行している。 & フジツボ，い貝 \\
\hline ステンレス鋼 $(25 \mathrm{Cr}-13 \mathrm{Ni}$ 系 $)$ 卷き $(3 \mathrm{~mm})$ & $\begin{array}{l}\text { 溶接部にさび色の変色があるが，腐食の進行は認め } \\
\text { られない.被覆境界部の無処理ぐいに凹凸腐食が多 } \\
\text { 数発生している. }\end{array}$ & フジツボ，い貝 \\
\hline 耐海水鋼 $(\mathrm{Cu}-\mathrm{Cr}-\mathrm{Al}$ 系) 巻き $(6 \mathrm{~mm})$. & $\begin{array}{l}\text { 全体的に腐食は進行している.干満带は比較的緻密 } \\
\text { なさざ層で覆われている. 被覆境界部の無処理ぐい } \\
\text { に凹凹腐食がみられる. }\end{array}$ & フジツボ，い貝 \\
\hline アルミ溶射 $(200 \mu \mathrm{m})$ （封孔処理） & $\begin{array}{l}\text { 大気〜飛沫带では白さびが点在し，干満帯では犠牲 } \\
\text { 防食効果のため，アルミの消耗が進んでいる. }\end{array}$ & $\begin{array}{l}\text { フジツボ, い貝 } \\
\text { 緑色のこけ }\end{array}$ \\
\hline $\begin{array}{r}\text { アルミ溶射 }(100 \mu \mathrm{m})+\text { タールエポキシ塗装 } \\
(300 \mu \mathrm{m} \times 2)\end{array}$ & $\begin{array}{l}\text { 大気部は塗膜の剝離，ふくれが数箇所発生している。 } \\
\text { 飛沫带干満帯で塗膜の剝離が著しく，アルミ溶射も } \\
\text { ほとんど消耗し，赤さびが発生している. }\end{array}$ & フジツボ, い貝 \\
\hline 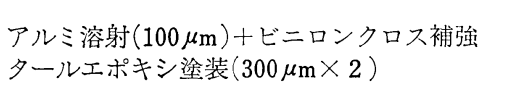 & $\begin{array}{l}\text { 大気〜飛沫带は塗膜の剝離が各所にみられ，赤さび } \\
\text { 及び白さびが混在している.千満帯では比較的大き } \\
\text { な塗膜の剝離があり，赤さびが発生している. }\end{array}$ & フジツボ, い貝 \\
\hline $\begin{array}{r}\text { 西鉛溶射 }(100 \mu \mathrm{m})+\text { タールエポキシ塗装 } \\
(300 \mu \mathrm{m} \times 2)\end{array}$ & $\begin{array}{l}\text { 大父〜飛沫带は比較的良好であるが，干満帯に大き } \\
\text { な叙膜の剝離があり，亚鉛溶射もほとんど消耗し， } \\
\text { 赤さび及び白さびが混在している. }\end{array}$ & フジツボ，い貝 \\
\hline $\begin{array}{l}\text { 無機ジンクリッチペイント叙装 }(75 \mu \mathrm{m}) \\
+ \text { タールエポキシ塗装 }(300 \mu \mathrm{m} \times 3)\end{array}$ & $\begin{array}{l}\text { 大気〜飛沫带は小さなきず，ふくれが数筒所みられ } \\
\text { る程度であるが，干満帯は比較的大きな塗膜の剥離 } \\
\text { があり，赤さび及び白さびが混在している. }\end{array}$ & フジツボ, い貝 \\
\hline $\begin{array}{l}\text { 無機ジンクリッチペイント塗装 }(75 \mu \mathrm{m})+ \\
\text { ガラスクロス補強エポキシ塗装 }(300 \mu \mathrm{m} \times 3)\end{array}$ & $\begin{array}{l}\text { 大気〜飛沫带には小さなきずが数箇所あり，若干発 } \\
\text { 錆しているが，干満帯の塗膜に異状は認められない。 }\end{array}$ & $\begin{array}{l}\text { フジツボ, い具 } \\
\text { 緑色のこけ }\end{array}$ \\
\hline ポリエチレン押出しライニング $(4 \mathrm{~mm})$ & 全般的に外観は良好 & フジツボ，い貝 \\
\hline $\begin{array}{r}\text { エポキシ系レジンモルタルライニング } \\
(4 \mathrm{~mm})\end{array}$ & $\begin{array}{l}\text { 大気部の大きなうちきずによる剝離及び一部の被覆 } \\
\text { にクラックの発生がみられる.全般的に薄いさび色 } \\
\text { を是している. }\end{array}$ & $\begin{array}{l}\text { フジツボ, い具 } \\
\text { 緑色のこけ }\end{array}$ \\
\hline $\begin{array}{l}\text { ファイバーコンクリートライニング } \\
\text { №.12(型枠: } 100 \mathrm{~mm} \text { ) No.12'(吹付计 }: 50 \mathrm{~mm} \text { ) }\end{array}$ & $\begin{array}{l}\text { 全面にスチールファイバーによる点線状のさびがあ } \\
\text { り，杭の上部に小さなクラックが生じている. }\end{array}$ & $\begin{array}{l}\text { フジツボ, い貝 } \\
\text { 緑色のこけ }\end{array}$ \\
\hline
\end{tabular}


表 5 飛沫部・干満部の防食技術の適用性 ${ }^{8)}$

\begin{tabular}{|c|c|c|c|c|c|c|}
\hline \multirow{2}{*}{ 防 食 法 } & & \multicolumn{2}{|c|}{ 人 工 島 } & \multirow{2}{*}{$\begin{array}{ll} & \text { 鋼 } \\
\text { 管 } \\
\text { 基 } & \text { 礎 } \\
\end{array}$} & \multirow{2}{*}{$\begin{array}{c}\text { ケー } \\
\text { ソン }\end{array}$} & \multirow{2}{*}{$\begin{array}{l}\text { 浮 体 } \\
\text { 構造物 }\end{array}$} \\
\hline & & 鋼矢板 & 鋼管矢板 & & & \\
\hline \multirow{2}{*}{ 㳂装 } & クロス材脈用なし & O & O & $\bigcirc$ & 0 & 0 \\
\hline & あり & $x$ & $\times$ & 0 & $x$ & $x$ \\
\hline \multirow{4}{*}{ 有機ライニング } & ポリエチレン(押出し) & $x$ & $x$ & 0 & $x$ & $x$ \\
\hline & " (粉末 $)$ & $\triangle$ & $\bigcirc$ & $\triangle$ & $\triangle$ & $\triangle$ \\
\hline & レジンモルタル & 0 & 0 & 0 & 0 & 0 \\
\hline & 䦿 食テープ & $x$ & $x$ & $\bigcirc$ & $x$ & $x$ \\
\hline \multirow{2}{*}{ 無機ライニング } & - & O & 0 & O & 0 & 0 \\
\hline & F R P 型枠使用 & $x$ & $\triangle$ & 0 & $x$ & $x$ \\
\hline 金 属 溶 射 & - & O & $\bigcirc$ & O & $\bigcirc$ & 0 \\
\hline 耐食性金属被覆 & - & O & 0 & 0 & O & $\bigcirc$ \\
\hline $\begin{array}{l}\text { 低合金系洏海水 } \\
\text { 鋼特特特:鉄板卷き }\end{array}$ & - & O & O & 0 & O & $\bigcirc$ \\
\hline
\end{tabular}

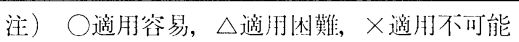

表 6 電気防食装置の設計基準 (代表的な例 $)^{10)}$

\begin{tabular}{|c|c|c|c|c|c|}
\hline & 環 & 境 & ，因 & 子 & 1) \\
\hline 域 & \begin{tabular}{|c|} 
海水抵抗 \\
$\left(\mathrm{oh}^{\prime} \mathrm{m}-\mathrm{cm}\right)$
\end{tabular} & \begin{tabular}{|l|} 
水温 \\
$\left({ }^{\circ} \mathrm{C}\right)$ \\
\end{tabular} & $\begin{array}{c}\text { 波 浪 作 用 } \\
\text { (Wave Action) }\end{array}$ & 潮 流 & $\begin{array}{c}\text { 代表的な設計電流密度 (2) } \\
\mathrm{mA} / \mathrm{ft}^{2}\left(\mathrm{~mA} / \mathrm{m}^{2}\right)\end{array}$ \\
\hline Gulf of Mexico & 20 & 22 & Moderate & Moderate & $5 \sim 6(54 \sim 65)$ \\
\hline U.S.West Coast & 24 & 15 & " & Low & $7 \sim 8(76 \sim 86)$ \\
\hline Cook Inlet & 50 & 2 & Low & High & $35 \sim 40 \quad(380 \sim 430)$ \\
\hline North Sea & 26 & 12 & High & Moderate & $8 \sim 15(86 \sim 162)$ \\
\hline Persian Gulf & 15 & 30 & Moderate & Low & $7 \sim 10(76 \sim 108)$ \\
\hline Indonesia & 19 & 24 & $"$ & Moderate & $5 \sim 6(54 \sim 65)$ \\
\hline
\end{tabular}

注(1）河口から離れた，平均的条件に基づいた代表的数值.

注(2) 通常の海水中では，上記設計電流密度によって分極が達成し，石灰質被膜が形成す ると，構造物を防食電位に保持するには設計优より小さい電流密度で十分である。

（注意）暴風雨により復極を生じることがある.

実際の海洋構造物で採用されている電気防食の設計基 準値の例を表 6 亿示す。また，近年行われた電気防食の 設計方法に関する研究の結果, 海洋環境条件に応じた防 食電位と防食電流密度の設計基準値として表 7 及び 8 の 值を取るべきことが明らかにされている。防食電位に応 じて儀牲陽極の種類, 初期電流密度に応じて陽極の設置 箇所数, 定常電流密度に応じて 1 箇所当たりの陽極重量 が定まる。

しかし, 陽極の設置籄所数は, 構造物の形状等によっ ても異なるはずであり，形状に応じた設置方法，メンテ ナンスを容易にするための設置方法など，海洋構造物の 種類に応じて適切な陽極の設置を行ら必要がある。ま た，電気防食をより合理的に行らために，電気防食と塗 装を併用することが考兄られ, 近年, 電気防食と併用す るための塗装材料が開発されてきている。
表 7 防食電位 (単位 $\mathrm{mV})^{11)}$

\begin{tabular}{|c|c|c|}
\hline 環 境 & 電気防食 & $\begin{array}{l}\text { 複合.電気防食 } \\
\text { (塗装併用). }\end{array}$ \\
\hline $\begin{array}{l}\text { 清 浄 海 域 } \\
\text { (低温, 希採環境を含む) }\end{array}$ & -770 & \multirow{3}{*}{$\begin{array}{l}-770 \\
\text { ただし下限を } \\
-1,100 \text { とする }\end{array}$} \\
\hline $\begin{array}{lll}\text { 污 染 海 } \\
\end{array}$ & -900 & \\
\hline 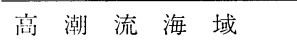 & 770 & \\
\hline
\end{tabular}

(vs. SCE)

\section{3. 浮遊式構造物用の係留系の防食技術}

\section{1 係留技術の現状}

浮遊式海洋構造物の場合, 定位置に固定するために構 造物を係留する必要がある。係留の方法として，索鎖に よって浮体を直接係留するカテリナ係留, ドルフィンに 浮体を係留するドルフィン係留等がある。係留材として チェーン及びロープが用いられている。一般にチェーン 
表 8 防食電流密度 $\left(\mathrm{mA} / \mathrm{m}^{2}\right)^{11)}$

\begin{tabular}{|c|c|c|c|c|c|}
\hline \multirow{2}{*}{\multicolumn{2}{|c|}{ 環 境 }} & \multicolumn{2}{|c|}{ 電気 防 } & \multicolumn{2}{|c|}{ 複合電気防食（涂装併用） } \\
\hline & & \multirow{2}{*}{\begin{tabular}{|c|} 
被期防食電流 \\
100 \\
莨 \\
100
\end{tabular}} & $\begin{array}{r}\text { 定常防食電流 } \\
\text { 喥 }\end{array}$ & $\begin{array}{l}\text { 初期防食電流 } \\
\text { 度 }\end{array}$ & \multirow{2}{*}{$\begin{array}{l}\text { 㸃常防食電流 } \\
\text { 左記の値に叙 }\end{array}$} \\
\hline \multirow{2}{*}{$\begin{array}{l}\text { 清 浄 海 域 } \\
(\text { 低温, 希 } \\
\text { 環境を含む) }\end{array}$} & 海水中 & & 50 & \multirow{7}{*}{$\begin{array}{l}\text { 左記の值に洽 } \\
\text { 膜のはく離率 } \\
\text { を乗じた値 }\end{array}$} & \\
\hline & 土 中 & 20 & 10 & & \multirow{6}{*}{$\begin{array}{l}\text { 膜のはく離率 } \\
\text { を乗じた值 }\end{array}$} \\
\hline \multirow{3}{*}{ 污 染 海 域 } & 海水中 & $100 \times K$ & $50 \times \mathrm{K}$ & & \\
\hline & ヘドロ中 & 150 & 100 & & \\
\hline & 土 中 & $20 \times K$ & $10 \times \mathrm{K}$ & & \\
\hline \multirow{2}{*}{ 高潮流海域 } & $2 \mathrm{~m} / \mathrm{s}$ & 230 & 115 & & \\
\hline & $5 \mathrm{~m} / \mathrm{s}$ & 270 & 135 & & \\
\hline
\end{tabular}

備考：Kは污染の程度に応じて1.2より1.5までの範囲とする．

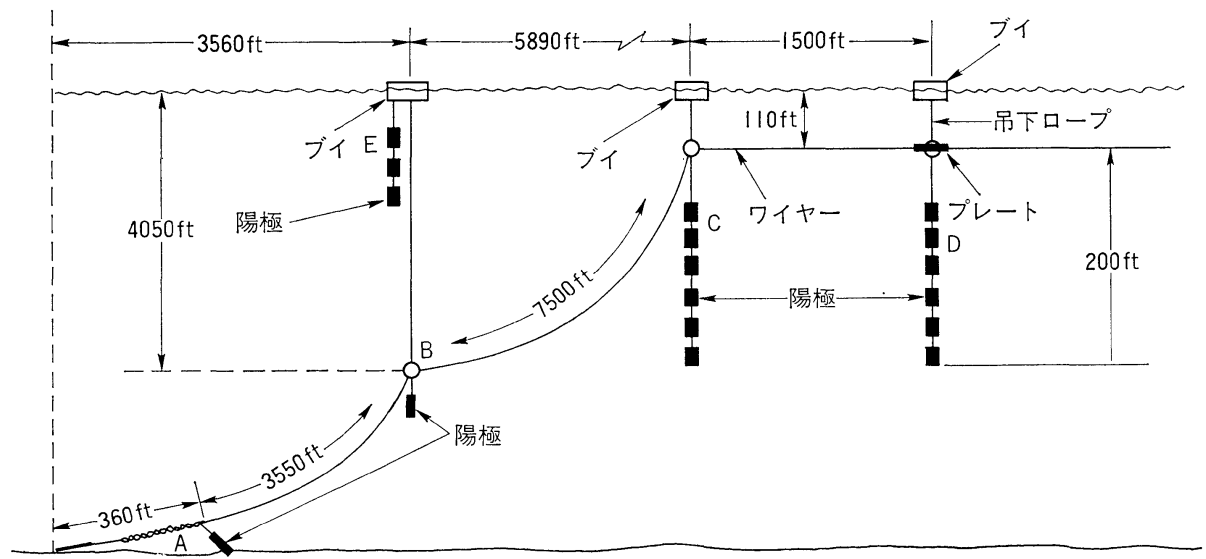

ワイヤ：亜鉛メッキの上に歴青質塗装

海中金具：亚鉛メッキ

$100 \mathrm{lb}(45 \mathrm{~kg})$ 陽極 6個

錨と錨鎖：裸鋼

$60 \mathrm{lb}(27 \mathrm{~kg})$ 陽極33個

図 7 BAHAMA 島沖深海ブイの電気防食 ${ }^{12)}$

には高張力鋼，ロープにはワイヤーロープ及び合成繊維 ロープ (ナイロン等) が用いられている。しかし，従来 係留系の損傷による浮体の流出事故が多く，その対策が 問題となっている。一般には 1 2 年ごとに点検補修を 行い，数年で取り替える必要があるといわれている。係 留系の損傷原因には，衝突，突風，台風等による設計值 以上の衝撃力の作用と係留材の摩耗腐食, 疲労腐食によ る劣化が考兄られている。

\section{2 係留系の防食技術と問題点}

係留系の防食には一般に犠牲陽極による電気防食が行 われている。図 7 及び 8 亿電気防食例を示す。係留系で は摩耗腐食及び疲労腐食の影響を受けるため, その設計 に当たっては，構造技術の面と防食技術の面と両面から のつめが不可欠である。しかし，実際の海洋環境での係 留系の摩耗腐食及び疲労腐食については不明な点が多 く，またその電気防食の効果についても充分な解明がな されていず，係留系の防食技術はまさに今後の研究課題

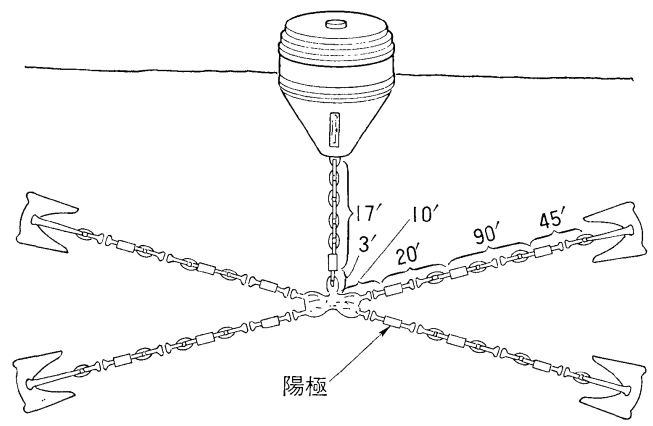

図 8 ブイチェーンの電気防食 ${ }^{13)}$

といえる。浮遊式海洋構造物の実用化をはかるには，防 食技術を含めた係留システムの総合的な開発が不可欠で ある。

\section{4. あとがき}

海洋構造物の防食技術には，今後開発していくべき技 
術的問題点が多く残されている。現在, 各方面で積極的 に技術開発が行われているが，なかでも科学技術振興調 整費による「海洋構造物による海洋空間等の有効利用に 関する研究」の一環として実施されている「海洋構造物 の耐久性向上技術の開発に関する研究」では, 各省庁は もとより民間機関が協力して, 海洋構造物の防食技術に 関する研究が総合的に実施されており，今後の成果が期 待されている。

(1986 年 4 月 14 日受理)

\section{文献}

1) H. A. Humble: Corrosion 5, 292 (1949).

2) 栄 幸雄：金属材料, 10, [9], 12 (1970).

3）小若正倫浪か：住友金属, 19, [2] (1967).

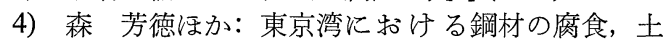
木技術資料，16, [11] (1974).
5）建設省土木研究所ほか：東京湾における鋼材の 腐食防食試験, 土木研究所資料, No. 1245 (1977).

6) F. M. Reinhart: U.S. Naval Engineering Laboratory, Technical Note, N-900 (1967).

7) 鋼材俱楽部: 海洋構造物の設計施工指針, (1976).

8) 建設省土木研究所：海洋構造物の保守管理技術 に関する報告畫, (1982).

9）鋼管杭協会：鋼管杭とその海洋ばくろ試験 記 録 (その 10) (1983).

10) NACE Standard RP-01-76: 固定式沖合プラット フォーム, (1976).

11）建設省土木研究所, (財) 土木研究センター：電気 防食設計指針・同解説 (1985).

12) L. J. Waldron et al.: Mater. Prot. 4, [8] (1965).

13) R. W. Drisko: Ocean Industry, (1972). 